\title{
Fetal anomalies in prolonged gestation in Awassi ewe: A case report
}

\author{
U.T. Naoman, B.D.I. Al-Watar, E.H. Lazim and E.K. Hussein \\ Department of Surgery and Theriogenology, College of Veterinary Medicine, University of Mosul, Mosul, Iraq
}

(Received January 15, 2018; Accepted February 19, 2018)

\begin{abstract}
This report was described the observation of five types of congenital anomalies with a Hydramnios Syndrome in prolonged gestational (6 months) three years old awassi ewe bearing an abnormal fetus for first time, ultrasonography revealed signs of pregnancy with numerous small cotyledon, high amount of bright turbid fluid (Hyper-genic), with no signs of heart beat and small abnormal ribs. Vaginal examination indicated that complete closure cervix with pale mucous membrane.
\end{abstract}

Keywords: Fetal, Anomalies, Hydropsy, Gestation, Awassi

Available online at http://www.vetmedmosul.com

$$
\begin{aligned}
& \text { التشوهات الجنينية لحالة الحمل الطويل في نعجة عواسية: تقرير حالة } \\
& \text { عدي طلعت نعمان، براء دريد إبراهيم الوتار، ايمان حياوي لازم والياس خضر حسين } \\
& \text { فرع الجراحة و علم تناسل الحيوان، كلية الطب البيطري، جامعة الموصل، الموصل، العراق }
\end{aligned}
$$

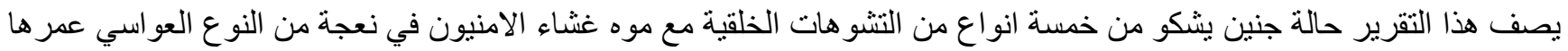

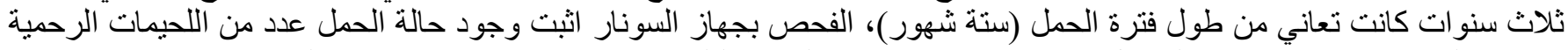

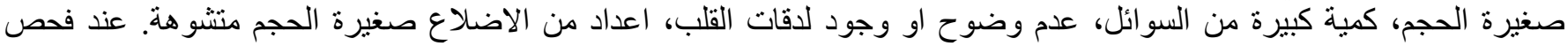
المهبل كان عنق الرحم مغلق تماما مع شحوب الانية الاغشية الطلائية.

\section{Introduction}

Fetal anomalies refer to fetal malformation or fetal abnormalities; they are one of the causes of dystocia in ruminants $(1,2)$. It is caused by genetic and environmental factors are necessary for defective development to occur (3). Other causes like teratogenic agents, drugs, hormones, chemicals, Gamma radiation, trace elements, variation in temperature, an infectious agents (virus, parasite, bacteria...etc.) and unknown causes $(4,5)$. Fetal membranes surrounded fetus that provided an environment for fetus generation, protection and facilitate birth, Hydrops of amnion mean excessive accumulation of fluid in amniotic sac, this condition may be as a result of prolonged gestation combining with fetal abnormalities (4). Prolonged gestation refers to condition in which the gestation period more than the normal rang without signs of delivery or start of delivery and the fetus is excessively large or malformed in most cases $(4,5)$.

\section{History and clinical signs}

The involved ewe was three years old brought by the owner to the clinic of College of Veterinary Medicine, University of Mosul, and he claimed that the ewe about six months of gestation and without any signs of parturition. In addition, he said that the mammary gland relaxed at first time but then became tensed with big size of abdomen.

On clinic, the first step is to being ensure that the ewe was pregnant, milk examination by squeezing tits that showed no signs of colostrum, further that: there are no signs of ligamentous relaxation in the pelvis. Ultrasonography examination is done by using B- mode ultrasonography as same way described by $(6,7)$. The 
ultrasonography showed a sign of pregnancy with numerous small cotyledon, high amount of bright turbid fluid (Hyper-genic) with no signs of heartbeat. The ribs are small with abnormal figure. Vaginal examination indicated that complete closed cervix with pale mucous membrane.

\section{Treatment}

The ewe was about 45 K.G body weight, alert with good body condition. According to the clinical findings, cesarean section was indicated to treat this case as away described by Kenneth and David (8) and Ali (9). The animal was restrained, clipped and shaved, left ventro-lateral approach was chosen as a site of operation, local anesthesia by using $10 \mathrm{ml}$ of lidocaine hydrochloride $2 \%$, and then open the skin, abdominal muscles, peritoneum and the graved horns of uterus (right). While opening the uterus, high amount of amniotic fluid flowed out from it, its look like thick white in color. The fetus was remove from uterus, its stillbirth (about 1-2 minutes of life), with five types of fetal abnormalities, which were facial anomalies including: split jaw, cleft palate, parotid mouth and hydrocele sac, which protruded from fetal skull (figures 1, 2). Abdominal anomalies including: atrophied right hind limb, schistosomus reflexus and abdominal content show out of the fetal body (figures 3, 4). After fetal delivering, suturing the uterus, muscle with internal suture technique and skin sutured with horizontal matters technique. The animal was given 1 million IU procaine penicillin $\mathrm{G}$ with $1 \mathrm{~g}$ of dihydrostreptomycin IM daily for 5 days, oxytocin 20IU/IM and $\mathrm{Ca}$ progloconate $40 \mathrm{ml} / \mathrm{SC}$ injection, and oxytetracycline as wound spray (OTC spray). After one week the owner reported, that the ewe doing well. this is the first record of five fetal abnormalities in same fetus.

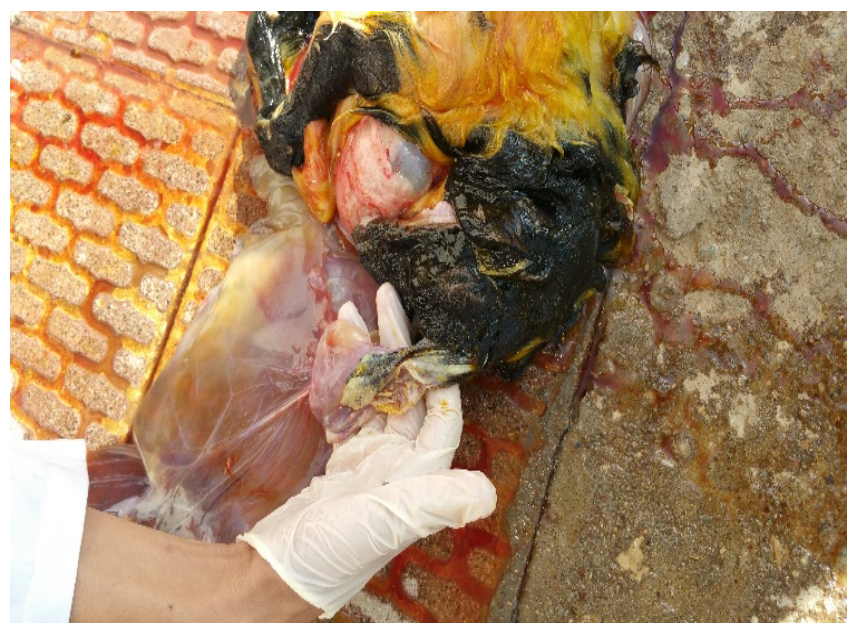

Figure 1: Showed hydrocele sac protruded from the fetus skull.

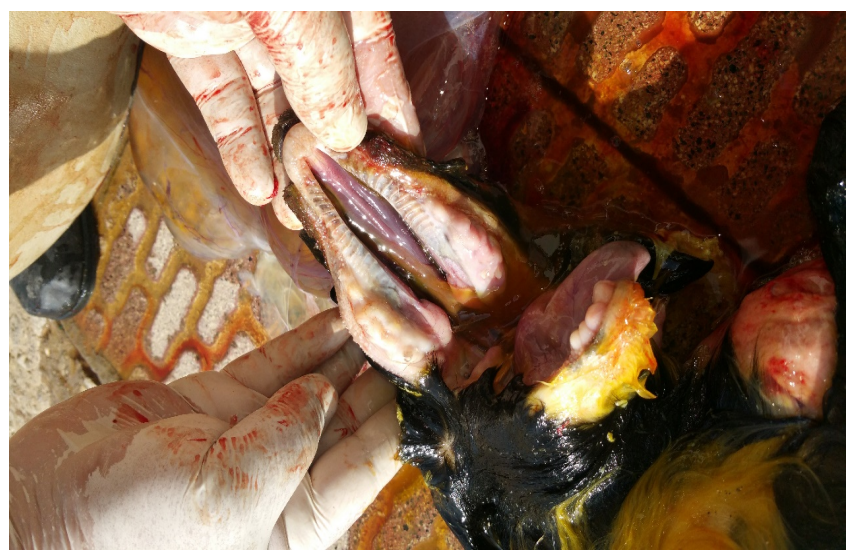

Figure 2: Showed cleft palate abnormality, cleft palate, split jaw and parotid mouth in fetal skull.

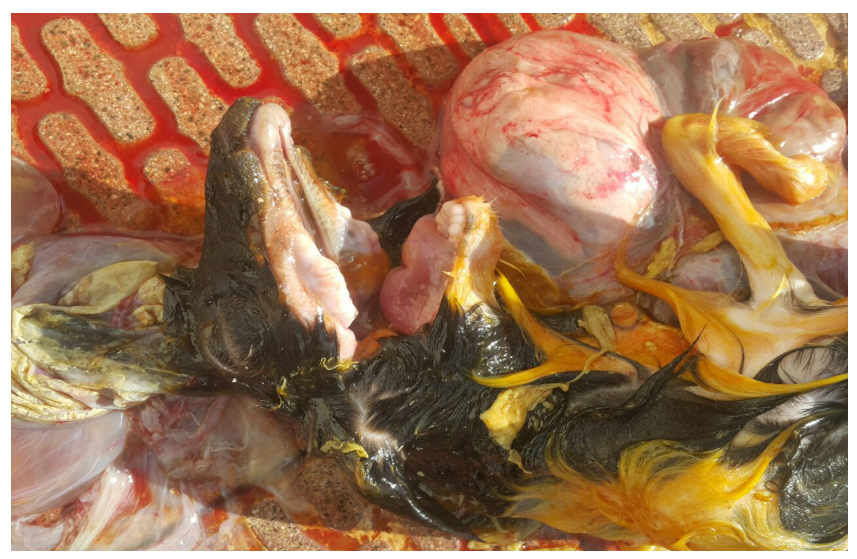

Figure 3: Showed atrophied right hind limb and fetal content out of the fetal body (schistosomus reflexus).

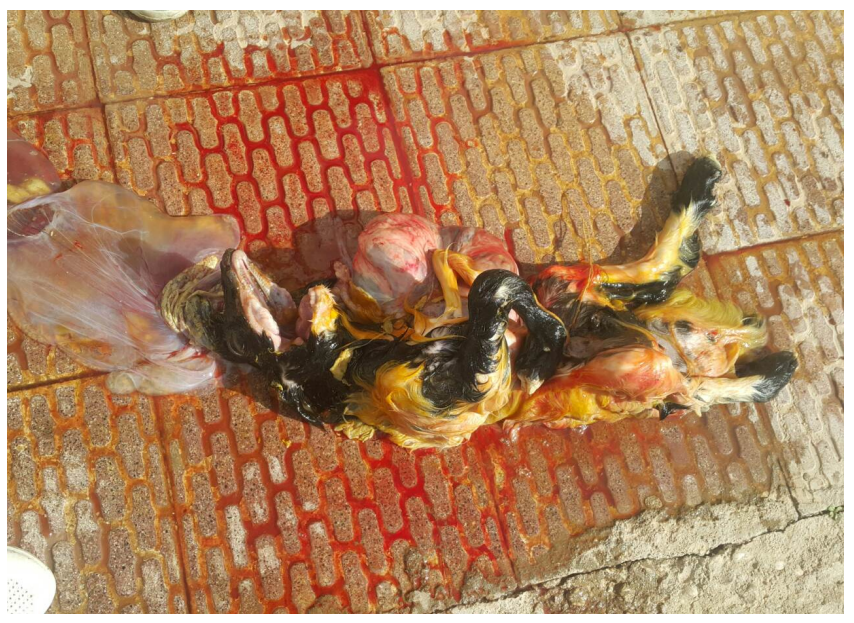

Figure 4: Showed five abnormalities in fetal head and abdomen. 


\section{References}

1. Noakes DE, Parkinson TJ, England GCW, Arthur GH. Arthur's veterinary reproduction and obstetrics. 8th ed, Elsevier Sci Ltd. 2002;pp:119-141.

2. Roberts SJ. Hereditary or congenital anatomic defects of the reproductive tract. In: Veterinary obstetrics and genital diseases (Theriogenology). Third Ed Woodstock: SJ Roberts. 1986,pp:520533.

3. Jackson PGG. Handbook of veterinary obstetrics. 2nd ed, Elsevier Sci Ltd, 2004;pp:17-29.

4. Majeed AF, Alwan AF, Ali JB, Juma FT, Azawi OI. Congenital defects causing dystocia in ruminants. Iraqi J Vet Med. 1992;5:85-95.
5. Basher EB. Clinical study of fetal congental defects causing dystocia in awwasi ewes. Iraqi J Vet Med. 2006;20:181-189.

6. Descoteaux L, Gnemmi G, Colloton J. Practical atlas of ruminants and camelid reproductive ultrasonography. Wiley-black publisher. 2010;pp:197-198.

7. Lazim EH. Estimation of gestational age in cows using transabdominal ultrasonographic measurements. Msc thesis: Mosul University, Mosul, Iraq, 2016.

8. Kenneth D, David E. Cesarean section in cows. Vet Clin Food Anim. 2005;21:73-100.

9. Ali AM. Causes and treatment of dystocia in small ruminants in Saudi Arabia. J. Agric Vet Sci. 2011;4:95-188. 